\title{
Estudio longitudinal de competencia científica
}

\author{
Falicoff, Claudia B. $;^{1}$ Manni, Diego C. ${ }^{2}$ Domínguez Castiñeiras, José M.; ${ }^{3}$ \\ Fernández, Elena T.; $;^{2}$ Odetti, Héctor $\mathrm{S}^{3}$
}

\section{Resumen}

En el presente estudio longitudinal se presentan resultados que ponen de manifiesto el desarrollo de la competencia científica de los estudiantes en el Ciclo Básico de las carreras de Bioquímica y de Licenciatura en Biotecnología de la Facultad de Bioquímica y Ciencias Biológicas de la Universidad Nacional del Litoral Santa Fe, Argentina. Para obtener la información, se elaboraron cuatro cuestionarios ad hoc con preguntas que abarcan las tres sub-competencias científicas analizadas: Identificar cuestiones científicas (ICC), explicar fenómenos científicamente (EFC) y utilizar pruebas científicas (UPC).

Aunque con fluctuaciones durante los años de estudio, los resultados revelan que el desarrollo es favorable con el siguiente orden de prioridad: ICC, EFC y UPC. Esto ocurre de manera más apreciable en Bioquímica que en Biotecnología.

Palabras clave: competencia científica, estudio longitudinal.

Presentado: 3-8-13 | Aceptado: 22-10-13

${ }^{1}$ Departamento de Química General e Inorgánica. Facultad de Bioquímica y Ciencias Biológicas. UNL. Ciudad Universitaria Paraje El Pozo. CC 242. (3000) Santa Fe. Argentina. falicoff@fbcb.unl.edu.ar; hodetti@fbcb.unl.edu.ar

${ }^{2}$ Departamento de Matemática. Facultad de Bioquímica y Ciencias Biológicas. UNL. Ciudad Universitaria Paraje El Pozo. CC 242. (3000) Santa Fe. Argentina. diegomanni@gmail.com ; elenacarrera2@ gmail.com

${ }^{3}$ Departamento de Didáctica das Ciencias Experimentais. Facultade de Ciencias da Educación. USC. Av. Xoan XXIII, s/n. 15782, Santiago de Compostela. España. ddacabdz@gmail.com 


\section{Summary}

\section{Longitudinal study of scientific competence}

This longitudinal study presents results that show the development of the scientific competency of students in the Basic Cycle of Biochemistry and Biotechnology

at Universidad Nacional del Litoral de Santa Fe, Argentina. To collect the information, four ad hoc questionnaires were drafted with questions addressing three scientific sub-competencies: Identifying scientific issues (ISS), explaining phenomena scientifically (EPS) and using scientific evidence (USE).

Although fluctuations during the years of study, the results reveal that the development is favorable with the following order of priority: ISS, EPS and USE. This is more noticeable in Biochemistry than in Biotechnology.

Keywords: scientific competency, longitudinal study. 